\title{
Screening of biofouling activity in marine bacterial isolate from ship hull
}

\author{
${ }^{1 *}$ D. Dhanasekaran; ${ }^{1} N$. Thajuddin; ${ }^{2} M$. Rashmi; ${ }^{2}$ T. L. Deepika; ${ }^{3} M$. Gunasekaran \\ ${ }^{1}$ Department of Microbiology, School of Life Sciences, Bharathaidasan University, Tiruchirappalli 620 024, India \\ ${ }^{2}$ Division of Environmental Biotechnology, School of Biotechnology, Chemical and Biomedical Engineering, VIT \\ University, Vellore-632014, India \\ ${ }^{3}$ Department of Biology, Fisk University, Nashville, TN, USA
}

Received 13 April 2008; $\quad$ revised 27 December 2008; accepted 20 January 2009; available online 1 March 2009

\begin{abstract}
Biofouling is the undesirable accumulation of microorganisms, plants, algae and animals on submerged structures especially ship hulls. Biofouling also occurs on the surface of living marine organisms. It is also found on membrane systems such as membrane bioreactors and reverse osmosis spiral wound membranes. In the same manner, it is found in cooling water cycles of large industrial equipments and power stations. In the present study, totally 11 isolates were obtained from three ships from Royapuram harbour, Chennai, Tamil Nadu, India. Among the 11 isolates only DR4 showed maximum biofouling activity in the microtiter plate assay with a significant optical density of 0.596. Also an attempt was made to characterize the different biofouling bacterial isolates analyzing their morphological, biochemical and molecular characteristics. The results of the present study based on the above characteristics revealed that the isolate DR4 was similar to Bacillus sp. This study also highlights the need for a safe and natural antifouling agent to control the biofouling bacteria in the marine environment.
\end{abstract}

Keywords: Memberane system, biofilm, phylogenetic analysis, Bacillus sp.

\section{INTRODUCTION}

In the marine environment, competition for living space is intense; therefore, all surfaces living or innate are susceptible to fouling. This process generally begins with the formation of a biochemical conditioning film on to which bacteria and other microorganisms colonize (Costerton and Lappin-Scott, 1995). Closely following the microbial fouling is the colonization of various eukaryotic organisms, including marine invertebrates and algae (Loeb and Neihof, 1975). Biofouling is divided into microfouling, a biofilm formation and bacterial adhesion and macrofouling, an attachment of larger organisms, of which the culprits are barnacles, mussels, polychaete worms, bryozoans and sea weeds (Melo and Bott, 1997). Biofouling is directly related to the presence of microorganisms which can damage the metal by adhering to different surfaces. Bacterial cells can encase themselves in a hydrated matrix of polysaccharides and proteins and form a slimy layer known as biofilms (Augustin and Vehmas, 2004; Vrouwenvelder et al., 2008). However, surface related attachment does not mean static; biofilms are very dynamic systems. Their formation is

× * Corresponding Author Email: dhansdd@yahoo.co.in

Tel.:+919 4862 58493; Fax: +9104312 407045 a progressive process in which colonizing bacteria move to or are transported to a surface, attach and through a series of steps, produce a biofilm (Guiamet and Gomez De Saravia, 2005; Mayer et al., 1999). The primary colonizers of any fresh surface are predominantly bacteria and diatoms. Marine organisms like Vibrio proteolyticus (Paul and Jeffrey, 1985), Escherichia coli, Pseudomonas aeruginosa, Shewanella oneidensis (Lee and Newman, 2003) and Bacillus subtilis (Omoike and Chorover, 2004) have been found to be involved in the biofouling process. Bacterial colonization occurs via a two step process beginning with reversible attachment to the substratum followed by irreversible adhesion (Dexter, 1979; Morisaki et al., 1999). The reversible attachments of cells are held by physical forces and can be easily removed by gentle washing. Non reversible attachment of cells is often mediated via specific mechanisms such as hydrogen bonding, cation bridging, specific receptor ligand interactions and the production of extracellular polysaccharides (EPS) (Biancitto et al., 2001; Jayaraman and Seetharaman, 2003). In ships, the adverse effects caused by this biological settlement are high fractional resistance, due to generated roughness, which leads 
to an increase of weight and subsequent potential speed reduction (Yebra et al., 2004). The biofouling bacteria were collected on October 2007 from biofilm samples at the Royapuram Harbour, Chennai, Tamil Nadu, India and screened for the biofouling activity.

\section{MATERIALS AND METHODS}

Sample collection

The biofilm samples were scraped from three different ships anchored at the Royapuram Harbour, Chennai, Tamil Nadu and were brought to the laboratory in sterile polythene bags for further investigation.

\section{Isolation of bacteria}

The collected samples were serially diluted and plated over Zobell agar plates. The inoculated plates were incubated at $28 \pm 2{ }^{\circ} \mathrm{C}$ for $24-48 \mathrm{~h}$. After incubation, the selected bacterial colonies were purified and subcultured in nutrient agar medium for further investigation (Saravanan et al., 2008).

Screening of biofouling activity in bacterial isolates by microtiter plate assay

The bacterial isolates were grown over night in nutrient broth at $37^{\circ} \mathrm{C}$. Aliquots of $3 \mu \mathrm{L}$ were inoculated in six parallel wells of a 96 well microtiter plate. Then the plate was incubated at $37^{\circ} \mathrm{C}$ for $72 \mathrm{~h}$. After the incubation period, the wells were rinsed with physiological saline to remove the detached cells and fixed with $2 \mu \mathrm{L}$ of $99.99 \%$ ethanol for $10 \mathrm{~min}$. The attached bacterial material was then stained adding 2 $\mu \mathrm{L}$ of crystal violet (2\%) for $20 \mathrm{~min}$. The plate was rinsed with tap water and the amounts of attached cells were measured using an ELISA reader at $570 \mathrm{~nm}$ (AbdiAli et al., 2006; Peeters et al., 2008).

\section{Characterization of biofouling bacteria}

Morphological and biochemical characterization

The isolate which showed maximum biofouling activity was then characterized using various morphological, biochemical and molecular characters. Gram staining and motility tests were performed for preliminary identification of the isolate (Allegrucci and Sauer, 2007). Morphological parameters include colony color, size, shape and margin; biochemical tests such as catalase, sugar fermentation and nitrate reduction were carried out (Dalton et al., 1994).

\section{Molecular characterization}

The chromosomal DNA was isolated (Bollet et al., 1955) from the DR4 isolate by alkali lysis method and subsequently amplified by PCR using the universal forward and reverse primers 5' AGAGTTTGATC CTGGCTCAG3' and 5'ACGGCTACCTTGTTACG ACT3', respectively. The following parameters were used for PCR (Weisburg et al., 1991) amplification: 30 cycles of initial denaturation step at $94^{\circ} \mathrm{C}$ for $2 \mathrm{~min}$, followed by denaturation step at $94{ }^{\circ} \mathrm{C}$ for $45 \mathrm{sec}$, annealing at $52{ }^{\circ} \mathrm{C}$ for $30 \mathrm{sec}$, extension at $72^{\circ} \mathrm{C}$ for 1 min and final extension at $72{ }^{\circ} \mathrm{C}$ for $2 \mathrm{~min}$. The PCR product was resolved by $1 \%$ agarose gel stained with ethidium bromide and the amplicon was sent for sequencing to First-Base, Singapore. Specific primer 5'GTATTACCGCGGCGTGCTGG 3' was provided along with the sample for sequencing. The nucleotide sequence obtained was compared with the known bacterial sequences available in the NCBI database using the bioinformatics tool BLAST and a phylogenetic tree was constructed using the PHYLIP program (Janet et al., 2000). The secondary structure of the bacterial 16S rDNA was predicted using Genbee software. The restriction sites present on the bacterial 16S rDNA was analyzed using the NEB Cutter program.

\section{RESULTS AND DISCUSSION}

In the present study, the biofilm samples were collected from three different ships. The samples were plated on Zobell agar medium for bacterial isolation. Totally 11 isolates were obtained: 3 isolates from ship I, 3 isolates from ship II and 5 isolates from ship III. The diversity of bacterial isolate was increased due to the nutritive status of water. The biofouling bacteria have already been reported from different habitats. Sillankorva et al. (2008) has isolated Pseudomonas fluorescence from biofilm samples, Kreig and Hoit (1984) and Sonak and Bhosle (1995) have isolated Vibrio alginolyticus from Tin panel associated biofilm, Chaudhary et al. (1996) have isolated Aerobacter aerogens and Bacillus alvei from various sites within a paper mill and Nidal et al. (2004) have isolated Escherichia coli from membrane systems. Thus, it is obvious that Bacillus spp. is adapted to diverse habitats which vary widely in space and time and also diverse environmental conditions. Totally 11 isolates were obtained from three ships and named as RB1, RB1a, RB1b, RB2, RB21, RB22, DR1, DR2, DR3, DR4 and DR5. Among the 11 isolates, only DR4 showed 
maximum biofouling activity in the microtitre plate assay with a significant optical density (OD) of 0.596 . The other isolates did not show significant biofouling activity (Fig. 1).The microtitre plate method was done by AbdiAli et al. (2006). A similar biofilm screening has been done by Bhosale et al. (2002) using floating glass cover slips on the sterilized filtered sea water to check the adherence of Bacillus spp. and Pseudomonas spp., biofilms and then staining the cover slips with gentian violet. The different parameters namely morphological, biochemical and molecular characters were used for characterization and identification of bacterial isolate. The bacterial isolate DR4 was observed as pale colored circular colonies on Zobell agar medium. The staining report showed gram positive, rod shaped and nonmotile cells. Various biochemical characteristics of

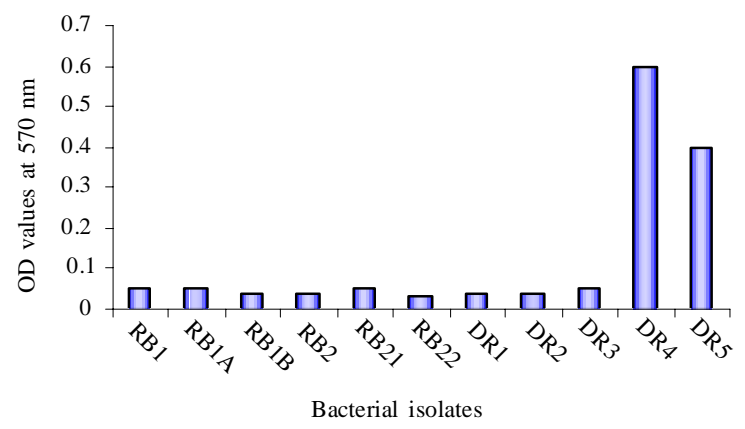

Fig. 1: Biofouling activity of the different bacterial isolates biofouling bacteria were used for their identification. In the present investigation, it was found that the bacterial isolate DR4 was found to be positive for catalase. It can ferment glucose, maltose and sucrose and reduced nitrates to nitrites (Table 1). Rajasekar et al. (2007) reported the presence of Bacillus spp., in corrosion product of pipe line and were characterized depending upon morphology, gram staining and biochemical tests. The classification of bacteria using morphological and physiological characteristics does not necessarily lead to the identification of phylogenetically coherent taxa. However, some of these characters were shown to be variable with changing media and environmental conditions. Several chemotaxonomic markers (isozyme patterns, fatty acid profile etc.) were used for species and strain level

Table 1: Morphological and biochemical characteristics of biofouling bacterial isolate DR4

\begin{tabular}{ccl}
\hline S. No & Name of the test & Result \\
\hline 1. & Gram staining & Positive \\
2. & Motility & Motile \\
3. & Lactose & Negative \\
4. & Catalase & Positive \\
5. & Glucose & Positive \\
6. & Maltose & Positive \\
7. & Sucrose & Positive \\
8. & Nitrate reduction & Positive \\
\hline
\end{tabular}

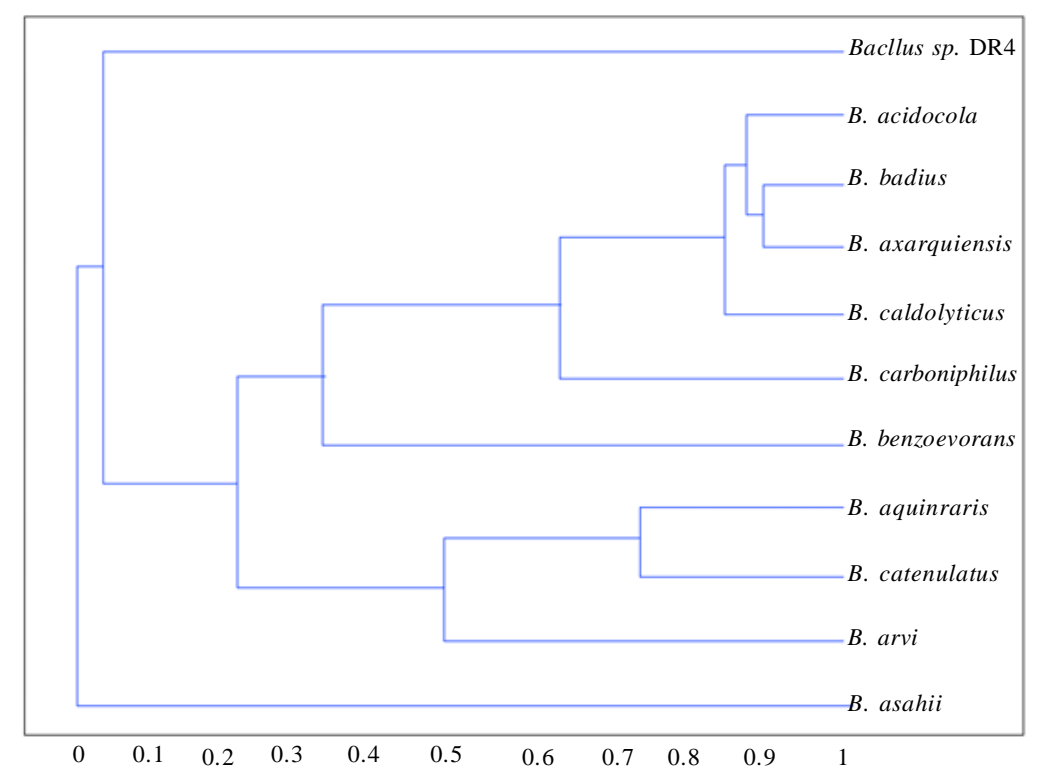

Fig. 2: 16S rDNA-based phylogenetic tree of Bacillus sp. DR4 with other Bacillus spp. sequence obtained from NCBI using Neighbor joining method 
differentiation with little success. To evaluate the bacteria, different polymerase chain reaction (PCR) based molecular methods namely $16 \mathrm{~S}$ rDNA sequencing, randomly amplified polymorphic DNA (RAPD), short tandemly repeated repetitive (STRR), etc. may be used at all taxonomic levels. The sequence analysis of genes encoding 16S rDNA is currently the most promising approach for phylogenetic classification of bacteria. The comparison of rDNA sequence is a powerful tool for detecting phylogenetic and evolutionary relationship among bacterial species. In the present study, the DNA was isolated from the bacterial isolate DR4 and was analyzed by agarose gel electrophoresis. A sharp band of genomic DNA was

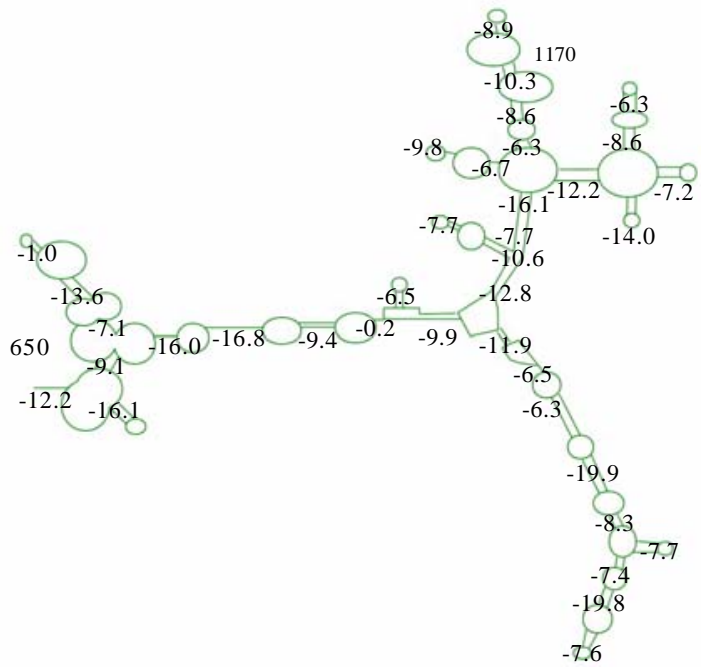

Fig. 3: Secondary structure of 16S rDNA of Bacillus sp., DR4 isolate using Genbee software obtained in the gel and 50 ng of DNA was used as template. The amplification 16S rDNA gene of the bacterial isolate DR4 was performed by PCR technique using universal primers. A sharp band was observed in $1 \%$ agarose gel which confirmed the presence of $16 S$ rDNA. The amplified 16S rDNA sample was sent to First-Base, Singapore for sequencing. The obtained nucleotide 16S rDNA sequence for the bacterial isolate DR4 was used for the basic local alignment search tool (BLAST) and the sequence showed similarity with the Bacillus sp. A phylogenetic tree of the isolate DR4 was constructed using its 16S rDNA sequence with that of the other Bacillus sp. obtained from the NCBI database. The resultant phylogenetic tree showed similarity of the isolate DR4 only at the genus level, whereas it did not show any similarity at the species level, hence DR4 was found in a separate branch (Fig. 2). A similar kind of results has been reported for Bacillus subtilis strains isolated from the biofilms of Gulf of Mexico (Jenet et al., 2000). The secondary structure of the bacterial 16S rDNA was showed 27 loops and 36 stems with an overall free energy of -190.1 kkal/mol (Fig. 3). The restriction sites present on the bacterial 16S rDNA showed 55 restriction sites and $42 \%$ and $58 \%$ GC and AC contents, respectively (Fig. 4).

The present study gives an idea about the presence of biofouling bacteria Bacillus sp., in the marine biofilm samples. It was characterized and identified using different parameters such as morphological, biochemical and molecular characters. Identifying a suitable natural antifouling agent against this

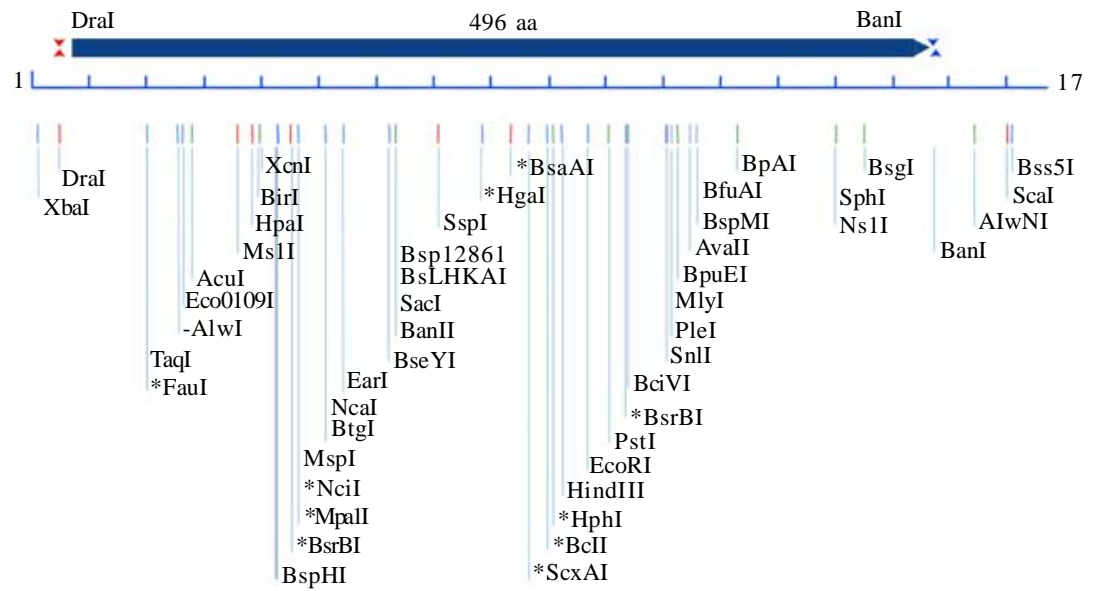

Fig. 4: Restriction site analysis of 16S rDNA of Bacillus sp., DR4 isolate using NEB Cutter program 
biofouling bacterium is thus suggested as further course of action.

\section{CONCLUSION}

The present investigation has clearly revealed the presence of biofouling bacteria in the marine biofilm samples collected from the ships anchored in the Royapuram harbor, Chennai, India. Morphological, biochemical and molecular characterization studies showed the diversity of different strains of Bacillus spp. and the biofouling activity of Bacillus sp. DR4. In order to minimize the economic loss, fuel consumption and metal corrosion due to the formation of biofilms, there is an urgent need for identifying suitable natural antifouling agents to control the biofouling bacteria which is abundant in the marine environments.

\section{ACKNOWLEDGEMENTS}

Authors are thankful to the VIT University to carry out the Research in Chemical and Biomedical Engineering School of Biotechnology and Authorities of Royapuram Harbour, Chennai, Tamil Nadu for their cooperation during sample collection.

\section{REFERENCES}

Abdi-Ali, A.; Mohammadi-Mehr, M.; A. Alaei., (2006). Bactericidal activity of various antibiotics against biofilm producing Pseudomonas aeruginosa. Int. J. Antimicrob. Agents., 27 (3), 196-200 (5 pages).

Allegrucci, M.; Sauer, K., (2007). Characterization of colony morphology variants isolated from Streptococcus pneumoniae Biofilms. J. Bacteriol., 189 (5), 2030-2038 (9 pages).

Augustin, M.; Vehmas, A. T., (2004). Assessment of enzymatic cleaning agents and disinfectants against bacterial biofilms. J. Pharm. Pharmaceut. Sci., 7 (1), 55-64 (10 pages).

Biancitto, V.; Andreotti, S.; Balestrini, R.; Bonfante, P.; Perotto, S., (2001). Extracellular polysaccharides are involved in the attachment of Azospirullum brasilense and Rhizobium leguminosarum to arbuscular mucorrhizal atructures. Eur. J. Histochem., 45 (1), 39-49 (11 pages).

Bhosale, S. H.; Nagle, V. L.; Jagtap, T. G., (2002). Antifouling potential of some marine organisms from India against species of Bacillus and Pseudomonas. Mar. Biotech., 4, 111-118 (8 pages).

Bollet, C.; Gevaudan, M. J.; Lamballerie, X.; Zandotti, C.; Micco, P., (1955). A simple method for the isolation of chromosomal DNA from Gram positive or acid-fast bacteria. Nucleic Acids Res., 19 (8), 4101-4102 (2 pages).

Chaudhary, A.; Gupta, L. K.; Gupta, J. K.; Banerjee, U. C., (1996). Studies on slime forming organisms in a paper millslime production and its control. J. Ind. Microbiol. Biotech., 18, 348-352 (5 pages).

Costerton, J. W.; Lappin-Scott, H. M., (1995). Introduction to Microbial Biofilms, in: Lappin- Scott, H. M.; Costerton,
J. W. (Eds.), Microbial biofilms, Plant and microbial biotechnology research series. University Press, Cambridge, UK. 5, 1-11.

Dalton, H. M.; Poulsen, L. K.; Halasz, P.; Angles, M. L.; Goodman, A. E.; Marshall, K. C., (1994). Substratum-induced morphological changes in a marine bacterium and their relevance to biofilm structure. J. Bacteriol., 176 (22), 69006906 (7 pages).

Dexter, S. C., (1979). Influence of substratum critical surface tension on bacterial adhesion - in situ studies. J. Collo. Inter. Sci., 70 (2), 346-354 (9 pages).

Guiamet, P. S.; Gomez De Saravia, S. G., (2005). Laboratory studies of biocorrosion control using traditional and environmentally friendly biocides: An overview. Latin Am. Appl. Res., 35, 295-300 (6 pages).

Janet, C. L.; Robert, A. B.; Alan, D. G., (2000). Structural maintenance of chromosomes protein of Bacillus subtilis affects supercoiling in vivo. J. Bacteriol., 184 (19), 53175322 (6 pages).

Jayaraman, M.; Seetharaman, J., (2003). Physiochemical analysis of the exopolysaccharides produced by a marine biofouling bacaterium Vibrio alginolyticus. Proc. biochem., 38 (6), 841-847 (7 pages).

Kreig, N. R.; Holt, J. G., (1984). Bergey's manual of Systemic Bacteriology. The Archaea and the Deeply branching and phototrophic bacteria. Vol. 1. Williams \& Wilkins.

Lee, A. K.; Newman, D. K., (2003). Microbial iron respiration: Impacts on corrosion processes. Appl. Microbiol. Biotech., 62, 134-139 (6 pages).

Loeb, G. I.; Neihof, R. A., (1975). Marine conditioning films. Adv. Chem., 145, 319-335 (17 pages).

Mayer, C.; Moritz, R.; Kirschner, C.; Borchard, W.; Maibaum, R.; Wingender, J.; Flemming, H. C., (1999). The role of intermolecular interactions: Studies on model systems for bacterial biofilms. Int. J. Biol. Macromol., 26 (1), 3-16 (14 pages).

Melo, L. F.; Bott, T. R., (1997). Biofouling in water systems. Experiment. Therm. Fluid Sci., 14, 375-381 (7 pages).

Morisaki, H.; Nagai, S.; Ohshima, H.; Ikemoto, E.; Kogure, K., (1999). The effect of motility and cell-surface polymers on bacterial attachment. Microbiology, 145 (10), 2797 2802 (6 pages).

Nidal, H.; Kochkodan, V.; Al-Khatib, L.; Levadna, T., (2004). Surface modified polymeric membranes to reduce biofouling: A microbiological study using E.coli. Desalination, 167, 293300 (8 pages).

Omoike, A.; Chorover, J., (2004). Spectroscopic study of extracellular polymeric substances from Bacillus subtilis: Aqueous chemistry and adsorption effects. Biomacromol., 5 (4), 1219-1230 (12 pages).

Paul, J. H.; Jeffrey, W. J., (1985). Evidence for separate adhesion mechanisms for hydrophilic and hydrophobic surfaces in Vibrio proteolytica. Appl. Environ. Microbiol., 50 (2), 431-437 (7 pages).

Peeters, E.; Nelis, H. J.; Coeny, T., (2008). Comparison of multiple methods for quantification of microbial biofilms grown in microtiter plates. J. Microbiol. Method., 72 (2), 157-165 (11 pages).

Rajasekar, A.; Ganesh, T.; Karuthapandian, S.; Maruthamuthu, S.; Palaniswamy, N.; Rajendran, A., (2007). Biodegradation and corrosion behaviour of manganese oxidizer Bacillus 


\section{Dhanasekaran et al.}

cereus ACE4 in diesel transporting pipeline. Corr. Sci., 49 (6), 2694-2710 (17 pages).

Saravanan, P.; Prabagaran, S. R.; Venkata Nancharaiah, Y.; Krishnaveni, M.; Venugopalan, V. P.; Jayachandran, S., (2008). Isolation and characterization of Pseudoalteromonas ruthenica (SBT033), an EPS-producing biofilm bacterium from the seawater intake point of a tropical power station. World J. Microbiol. Biotech., 24 (4), 509-515 (7 pages).

Sonak, S.; Bhosle, N., (1995). Observations on biofilm bacteria isolated from aluminium panels immersed in estuarine waters. Biofouling., 8 (3), 243-254 (12 pages).

Sillankorva, S.; Neubauer, P.; Azeredo, J., (2008). Pseudomonas fluorescens biofilms subjected to phage phiIBB-PF7A. BMC Biotechnology, 8 (79), 1-12 (13 pages)
Vrouwenvelder, J. S.; Manolarakis, S. A.; Hoek, J. P.; Paassen, J. A. M.; Meer, W. G. J.; Agtmaal, J. M. C.; Prummel, H. D.M.; Kruithof, J. C.; Loosdrecht, M.C. M., (2008). Quantitative biofouling diagnosis in full scale nanofiltration and reverse osmosis installations. Water Res., 42 (9), 48564868 (13 pages).

Weisburg, W. G.; Barns, S. M.; Pelletier, D. A.; Lane, D. J., (1991). 16S Ribosomal DNA amplification for phylogenetic study. J. Bacteriol., 173 (2), 697-703 (7 pages).

Yebra, D. M.; Kill, S.; Dam-Johansen, K., (2004). Antifouling technology-past, present and future steps towards efficient and environmentally friendly antifouling coatings. Prog. Organ. Coat., 50 (2), 74-104 (31 pages).

\section{AUTHOR (S) BIOSKETCHES}

Dhanasekaran, D., Ph.D., Lecturer, Department of Microbiology, School of Life Sciences, Bharathaidasan University, Tiruchirappalli 620 024, India. Email: dhansdd@yahoo.co.in

Thajuddin, N., Ph.D., Reader and Head of Department of Microbiology, School of Life Sciences, Bharathaidasan University, Tiruchirappalli 620 024, India. Email: nthaju2002@yahoo.com

Rashmi, M., M.Sc., M.Phil., Division of Environmental Biotechnology, School of Biotechnology, Chemical and Biomedical Engineering, VIT University, Vellore-632014, India. Email: rashmi.sharon@gmail.com

Deepika, T. L., M.Sc., Research fellow, Division of Environmental Biotechnology, School of Biotechnology, Chemical and Biomedical Engineering, VIT University, Vellore-632014, India. Email: deepika_tl@yahoo.co.in

Gunasekaran, M., Ph.D., Professor, Department of Biology, Fisk University, Nashville, TN, USA. Email: mgsekar@yahoo.com

This article should be referenced as follows:

Dhanasekaran, D.; Thajuddin, N.; Rashmi, M.; Deepika, T. L.; Gunasekaran, M., (2009). Screening of biofouling activity in marine bacterial isolate from ship hull. Int. J. Environ. Sci. Tech., 6 (2), 197-202. 